\title{
Mycorrhizae and Rhizobacteria on Precambrian Rocky Gold Mine Tailings: II. Mine-Adapted Symbionts Alleviate Soil Element Imbalance for a Better Nutritional Status of White Spruce Seedlings
}

\author{
Martin B. Nadeau', Joan Laur ${ }^{2 *}$ and Damase P. Khasa ${ }^{3 *}$ \\ ${ }^{1}$ Viridis Terra Innovations Inc., Sainte-Marie, QC, Canada, ${ }^{2}$ Institut de Recherche en Biologie Végétale, Université \\ de Montréal, Montréal, QC, Canada, ${ }^{3}$ Centre for Forest Research and Institute of Integrative and Systems Biology, \\ Université Laval, Quebec City, QC, Canada
}

OPEN ACCESS

Edited by:

Nuria Ferrol,

Consejo Superior de Investigaciones Cientificas (CSIC), Spain

Reviewed by:

Katarzyna Turnau,

Jagiellonian University, Poland Ivika Ostonen,

University of Tartu, Estonia

*Correspondence:

Joan Laur

joan.laur@umontreal.ca

Damase P. Khasa

damase.khasa@ibis.ulaval.ca

Specialty section:

This article was submitted to

Plant Microbe Interactions,

a section of the journal

Frontiers in Plant Science

Received: 23 March 2018

Accepted: 10 August 2018 Published: 03 September 2018

Citation:

Nadeau MB, Laur J and Khasa DP (2018) Mycorrhizae and Rhizobacteria on Precambrian Rocky Gold Mine Tailings: II. Mine-Adapted Symbionts Alleviate Soil Element Imbalance for a Better Nutritional Status of White Spruce Seedlings.

Front. Plant Sci. 9:1268.

doi: 10.3389/fpls.2018.01268
In the context of a phytorestoration project, the purpose of this study was to assess the respective contribution to the nutritional status of Picea glauca seedlings of ectomycorrhizae and rhizobacteria native or not to the Sigma-Lamaque gold mine wastes in northern Quebec, Canada. In a glasshouse experiment, inoculated plants were grown for 32 weeks on coarse waste rocks or fine tailings obtained from the mining site. The survival, health, growth, and nutritional status of plants were better on coarse waste rocks than on fine tailings. Fe and $\mathrm{Ca}$ were especially found at high levels in plant tissues but at much lower concentrations on waste rocks. Interestingly, inoculation of microsymbionts had only minimal effects on $\mathrm{N}, \mathrm{P}, \mathrm{K}$, and $\mathrm{Mg}$ plant status that were indeed close or within the concentration range encountered in healthy seedlings. However, both fungal and bacterial treatments improved $\mathrm{Fe}$ and $\mathrm{Ca}$ concentrations in plant tissues. Fe concentration in the foliage of plants inoculated with the fungi Tricholoma scalpturatum Tri. scalp. MBN0213 GenBank \#KC840613 and Cadophora finlandia Cad. fin. MBN0213 GenBank \#KC840625 was reduced by $>50 \%$. Both fungi were isolated from the mining site. The rhizobacteria, Azotobacter chroococcum, also improved plant Fe level in some cases. Regarding Ca nutritional status, the native bacterial strain Pseudomonas putida MBN0213 GenBank \#AY391278 was the only symbiont that reduced foliar content by up to $23 \%$. Ca concentration was negatively correlated with the fungal mycorrhization rate of seedling roots. This relation was especially strong $(r=-0.66, p$-value $\leq 0.0001)$ in the case of $C$. finlandia. Also, a similar relationship existed with root Fe concentration $(r=-0.44, p$-value $\leq 0.0001)$. In fact, results showed that seedling performance was more correlated with elevated $\mathrm{Ca}$ and $\mathrm{Fe}$ concentration in planta than with nutrient deficiency. Also, native microsymbionts were capable of regulating seedling nutrition in the poor substrate of the Sigma-Lamaque gold mine tailings.

Keywords: mycorrhizae, land reclamation, mine waste, nutrition, Picea glauca, rhizobacteria, toxicity 


\section{INTRODUCTION}

Anthropogenic activities such as mining of the Precambrian gold ores create severely disturbed ecosystems: most nutrients and minerals are trapped in the rock tailings, the only soil left. The situation is very similar to the natural process that occurs after glaciation retreat (Taner et al., 1986; Balogh-Brunstad et al., 2008) - yet, over time, many species recolonize this low fertility environment where organic matter is inexistent (Hobbie et al., 1998). Should it be cautiously designed, phytorestoration is an appropriate on-site management strategy for the reclamation of mine residues. Phytoremediation is an efficient, economically and ecologically sound solution (Nadeau, 2014; Vodouhe and Khasa, 2015).

Jumpponen et al. (2002) have studied the occurrence of ectomycorrhizae (ECM), the first mycorrhizal fungi present in primary succession (Trowbridge and Jumpponen, 2004), on the forefront of a retreating glacier. They found that pioneer plants were only able to thrive on the rock tailings in association with ECM. Like alder or spruce trees, all studied species (Salix commutata, S. phylicifolia, Abies lasiocarpa, Larix lyallii, Pinus contorta, and Tsuga mertensiana) are commonly known to form mycorrhizal symbiotic relationships (Dixon and Buschena, 1988; Nienstaedt and Zasada, 1990; Dahlberg, 2001; Quoreshi et al., 2007; Roy et al., 2007; Smith and Read, 2008). To thrive in harsh post-glacial conditions or human-made new ecosystems, plants have co-evolved with their microsymbionts capable of scavenging nutrients from rocks or fixing atmospheric nitrogen in exchange for plant photosynthetic carbon sources (Allen et al., 2003a,b; Khan, 2006; Roy et al., 2007; Quoreshi and Khasa, 2008).

One of the most characteristic trees of the boreal forest, white spruce (Picea glauca) has been known as a plastic species because of its wide distribution across North America and its ability to recolonize areas at the end of glaciation (Nienstaedt and Zasada, 1990). It can support extremely diverse site conditions in terms of temperature, moisture, light exposure or soil type (Sutton, 1973). White spruce seedlings were sporadically found regenerating on the Sigma-Lamaque gold mine tailings at Val d'Or, Abitibi, Quebec. This rocky soil is essentially made of biotite, an iron-rich mica (Taner et al., 1986). While considered at low risk for contamination (Beauregard et al., 2012), the mine waste material - a pile of coarse rocks and a basin full of fine ground tailings -, constitute a rather hostile environment for vegetation establishment because of its unbalanced mineral content, alkaline $\mathrm{pH}$, poor soil structure, and water holding capacity of the substrate. However, the rhizosphere of the healthy seedlings found on site revealed a community of fungi that is distinct from the adjacent nursery, forest edge, and natural forest ecosystems (Nadeau and Khasa, 2016).

By expanding the surface absorption of their hosts, fungi have the ability to increase water uptake and to extract insoluble forms of nutrients otherwise unavailable to the plant host (Balogh-Brunstad et al., 2008). Mycorrhizal associations have a tremendous potential to be used for land reclamation albeit some species and strains may be better adapted than others to the extreme site conditions of the Sigma-Lamaque mine tailings (Callender et al., 2016). Likewise, nitrogen-fixing bacteria have been found in the soil of all ecosystems including the boreal forest (Marshall, 2000). The inoculation of plant roots with plant growth promoting rhizobacteria (PGPR) of different genera including Acetobacter, Agrobacterium, Bacillus, Burkholderia, Mycobacterium, Pseudomonas, Rhizobium, Sphingomonas, and Staphylococcus has previously been shown to increase mineral accessibility to plants (reviewed in Rodríguez and Fraga, 1999; Tilak et al., 2005; Uroz et al., 2009; Dynarski and Houlton, 2018). For instance, Pseudomonas and Bacillus strains associated with maize roots of the Himalayan mountains showed marked P-solubilization activity (Zahid et al., 2015). Similarly, Burkholderia glathei inoculated on Scots pine roots (Pinus sylvestris) significantly increased plant $\mathrm{Mg}$ and $\mathrm{K}$ uptake from biotite substrate (Calvaruso et al., 2006). But in all these studies, the benefits conferred by the microsymbiotic association are unequal and site-, strain-, and/or plant specific. Although numerous reports list mycorrhizal fungi and PGPR that have been screened for their potential as biofertilizers in agriculture (see most recent references: Amin and Latif, 2016; Sritongon et al., 2017; Zahoor et al., 2017), the information on spruce trees interacting with a combination of fungal and bacterial symbionts under harsh conditions such as abandoned mine tailings of the Canadian north has never been studied before. In order to develop an efficient microbial consortium, it is necessary to test different microorganisms for the challenging stress and the synergistic interactions between fungi and bacteria in a way to form a basis of a cumulative impact on plant establishment.

Thus, to rapidly reforest the mining site, the main objective of the study was to assess the efficiency of selected allochthonous and indigenous mycorrhizal and bacterial symbionts in promoting adequate plant nutrition and in limiting toxicity of such an unfavorable substrate. A greenhouse experiment was conducted in which the establishment of white spruce seedlings on waste rocks or fine tailings of Sigma-Lamaque gold mine was evaluated. Both root and foliar nutrient concentrations $(\mathrm{N}$, $\mathrm{P}, \mathrm{K}, \mathrm{Ca}, \mathrm{Mg}, \mathrm{Fe}$ ) of white spruce seedlings were recorded after 32 weeks of growth during which seedling survival, health and growth parameters were also monitored (Nadeau et al., 2018). Results were comprehensively analyzed to refine our working hypothesis that favors the use of well-adapted microsymbionts directly isolated from the mining site over allochthonous ones.

\section{MATERIALS AND METHODS}

\section{Experimental Design and Treatments}

Detailed descriptions of the experimental design, treatments, growth and health measurements are presented in the companion paper (Nadeau et al., 2018).

Briefly, tailings collected directly from Sigma-Lamaque gold mine were used for this glasshouse trial. Three-week-old white spruce seedlings were grown in waste rocks or fine tailings and inoculated with or without a mycorrhizal fungus isolated from healthy naturally regenerating white spruce seedlings on Sigma-Lamaque gold mine coarse tailings (Nadeau and Khasa, 2016; Nadeau et al., 2016): Tricholoma scalpturatum Tri. scalp. MBN0213 GenBank \#KC840613 or Cadophora finlandia Cad. fin. 
MBN0213 GenBank \#KC840625; or Hebeloma crustuliniforme UAMH5247 from the Centre for Forest Research genomic and microbial collections ${ }^{1}$ and with or without nitrogen-fixing bacteria [Pseudomonas putida MBN0213 GenBank \#AY391278, Rhizobium radiobacter MBN0213 GenBank \#FR828334 isolated from the mining site; or Azotobacter chroococcum ATCC 9043 purchased from CEDARLANE Laboratories Ltd. (Ontario, Canada)]. The experiment was run for 32 weeks in a glasshouse at the Université Laval under semi-controlled conditions.

The study was designed as a randomized complete block (RCB) with three crossed fixed factors (Tailing type $\times$ ECM fungi $\times P G P R)$. There were 32 treatments including the controls with three replicates randomly placed within each of the four blocks for a total of 384 experimental units consisting of a $1.75 \mathrm{~L}$ pot containing one white spruce seedling (Supplementary Figure S1).

\section{Measurements of Seedling Health and Growth}

Detailed description of growth and health measurements are presented in the companion paper (Nadeau et al., 2018). Briefly, we used a portable fluorometer PAM-2000 with the data acquisition software DA-2000 (Heinz Walz, Effeltrich, Germany) to measure photochemical efficiency, we used WinSEEDLE to determine specific surface foliar areas (SSFA) of green, yellow, brown, dark red, and light red foliar tissues. Fresh needles, stem and roots were measured, weighted, and/or observed under a microscope to calculate the level of fungal colonization. Needles, stem and roots were dried for 7 days at $65^{\circ} \mathrm{C}$ to calculate the percentage of water content [(Fresh weight - Dry Weight)/Fresh weight]* 100 .

\section{Monitoring of Seedling Survival and Nutrient Content Analyses}

Seedling survival was assessed every 4 weeks through visual observations. Seedlings were considered dead when light red needles had no green color left.

For nutrient content analysis, replicates within treatments were pooled together in each block. Seedlings roots and needles were ground separately in a Wiley Mill. Samples were digested in concentrated $\mathrm{H}_{2} \mathrm{SO}_{4}$ and $50 \% \mathrm{H}_{2} \mathrm{O}_{2}$. Chemical analyses of nitrogen $(\mathrm{N})$, potassium $(\mathrm{P})$, phosphorus $(\mathrm{K})$, magnesium $(\mathrm{Mg})$, calcium $(\mathrm{Ca})$, and iron $(\mathrm{Fe})$ in roots and needles were performed on the digested tissues following techniques outlined in Kalra (1998) and Quoreshi and Khasa (2008). Other micronutrients were not measured because their concentrations in tailings were neither a limiting nor a toxic factor.

\section{Statistical Analyses \\ Differences Among Treatments}

As described in the compagnion paper (Nadeau et al., 2018), all the statistical analyses were conducted with the SAS software (SAS Institute Inc., 2012). Survival data were quantified in percentage and compared using $\chi^{2}$ test with PROC FREQ.

\footnotetext{
${ }^{1}$ http://www.cef-cfr.ca/index.php?n=CEF.Collections
}

Nutrient data were subjected to three-way analyses of variance (tailing type $\times$ fungi $\times$ bacteria) using PROC GLM. No transformation was necessary for root $\mathrm{N}, \mathrm{P}, \mathrm{K}, \mathrm{Ca}$, and $\mathrm{Mg}$ concentrations, and foliar $\mathrm{K}, \mathrm{Ca}$, and $\mathrm{Mg}$ concentrations. Log transformations were performed with root Fe concentration, and foliar N, P, and Fe concentrations.

Significance for all analyses was set at $\alpha=0.05(P \leq 0.05)$. Means and standard errors of each treatment were calculated for all variables.

\section{Correlation Analyses}

Correlations between the percentage of roots colonized by fungi and nutrient concentration variables were investigated using PROC CORR. Correlation analyses between health variables (photochemical efficiency, percentage of healthy green foliage, and percentage of dark red foliage), growth variables (root, stem, and needle dry biomass), and nutritional variables ( $\mathrm{N}, \mathrm{P}, \mathrm{K}, \mathrm{Mg}$, $\mathrm{Ca}$, and $\mathrm{Fe}$ concentrations in roots and foliage) were performed in order to determine which soil elements and concentration affected positively or negatively seedling health and growth. For these analyses, block means per treatment were used. Significance for all Pearson correlation coefficients $(r)$ was set at $\alpha=0.05$ $(P \leq 0.05)$.

\section{RESULTS}

\section{Plant Establishment on Mine Tailings}

Seedling mortality on both soil types began 8 weeks after the experiment started. While seedling mortality stabilized during the 16th week for the waste rock treatment, on fine tailings the percentage of seedling survival stopped decreasing during the 28th week only (Figure 1). Difference started to be significant after 20 weeks $(p$-value $=0.0158)$.

Most of the growth and health-related variables measured were independently affected by tailing type in the same manner

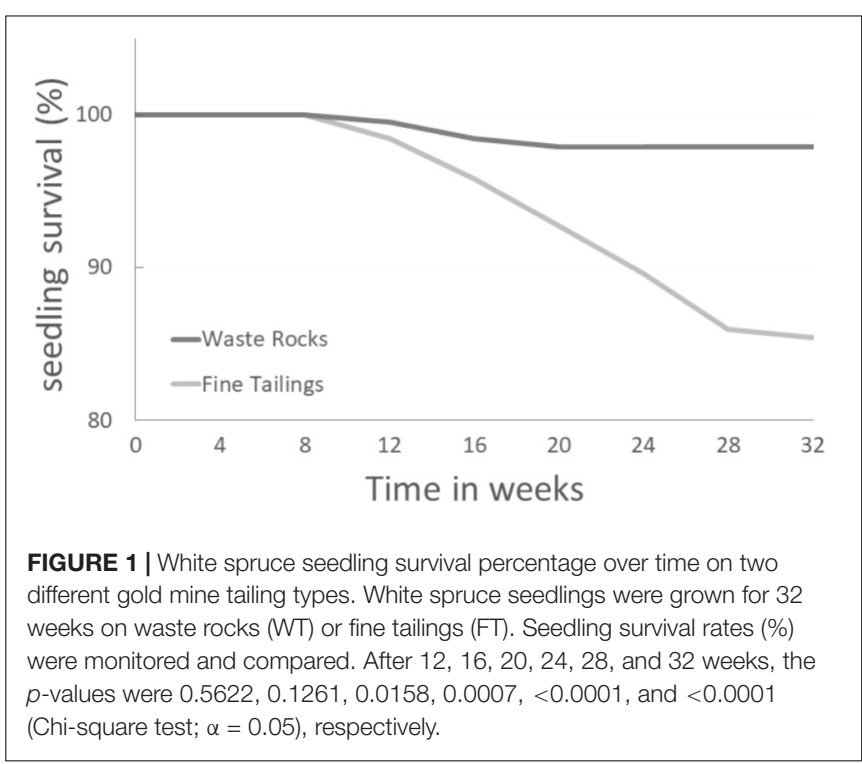


(Table 1). Seedlings grew much faster and healthier on waste rocks than on fine tailings. Aboveground, measured parameters diverged by up to $20 \%$ between the two treatments. Needle biomass, stem biomass and stem length were significantly higher for seedlings planted on waste rocks than those on fine tailings (all $p$-values $<0.0001)$. Belowground, the root system also benefited more from waste rocks tailing. Root biomass, root length, root area and root volume data of plants grown on waste rocks were $12 \%, 13 \%, 15 \%$, and $17 \%$ higher, respectively, than those grown on fine tailings (all $p$-values $<0.001$ ).

In agreement with survival rate and growth data, we found that plant health was also affected by tailing type. The percentage of dark red foliage (a bronzing symptom that can be associated with toxic mineral concentration) was much lower in seedlings grown on coarse waste rocks than on fine tailings ( $p$-value $<0.0001)$. Plant-water status was also improved for seedlings planted on waste rocks than for seedlings planted on fine tailings that exhibit a more conservative water-balance. On fine tailings, root water content was lower $(p$-value $=0.0278)$ and plants strictly maintained higher shoot water content $(p-$ value $<0.0001$ ) than on coarse waste rocks.

\section{Influence of Mineral Uptake on Plant Physiology}

Among the above-mentioned health and growth parameters, several were correlated with nutrient concentrations that could diverge widely in this experiment from concentration ranges encountered in perfectly healthy seedlings. This is particularly true for $\mathrm{Ca}$ and $\mathrm{Fe}$ for which concentrations were systematically recorded at levels exceeding the normal level by up to seven and 40 times but also for other elements [Table 2, measured concentration ranges diverging from the ones observed in healthy seedlings (Van den Driessche, 1991) are indicated in bold].

TABLE 1 | White spruce seedlings growth and health-related parameters affected by tailing type.

\begin{tabular}{lcr}
\hline & Waste rocks & Fine tailings \\
\hline Needle dry biomass (mg) & $33.9 \pm 0.8^{\mathrm{a}}$ & $27.2 \pm 0.9^{\mathrm{b}}$ \\
Stem dry biomass (mg) & $7.9 \pm 0.2^{\mathrm{a}}$ & $6.6 \pm 0.2^{\mathrm{b}}$ \\
Stem length (mm) & $24.2 \pm 0.3^{\mathrm{a}}$ & $21.7 \pm 0.3^{\mathrm{b}}$ \\
Root dry biomass (mg) & $51 \pm 1.4^{\mathrm{a}}$ & $44.7 \pm 1.4^{\mathrm{b}}$ \\
Total root length (mm) & $214.2 \pm 5^{\mathrm{a}}$ & $186 \pm 4.9^{\mathrm{b}}$ \\
Total root area (mm $\mathrm{mm}^{2}$ & $29.2 \pm 0.8^{\mathrm{a}}$ & $24.7 \pm 0.7^{\mathrm{b}}$ \\
Total root volume (mm $\left.{ }^{3}\right)$ & $0.32 \pm 0.01^{\mathrm{a}}$ & $0.27 \pm 0.1^{\mathrm{b}}$ \\
Dark red foliage (\%) & $13.9 \pm 1.3^{\mathrm{b}}$ & $18.1 \pm 1.4^{\mathrm{a}}$ \\
Root water content (\%) & $77.6 \pm 0.4^{\mathrm{a}}$ & $76.2 \pm 0.4^{\mathrm{b}}$ \\
Shoot water content (\%) & $48.4 \pm 0.3^{\mathrm{b}}$ & $51 \pm 0.3^{\mathrm{a}}$ \\
\hline
\end{tabular}

White spruce seedlings were grown for 32 weeks on waste rocks (WT) or fine tailings (FT). Belowground ground, root dry biomass $(\mathrm{mg})$, root volume $\left(\mathrm{mm}^{3}\right)$ and total root length $(\mathrm{cm})$ were affected by tailing type treatment. Aboveground, growthrelated parameters affected by tailing type treatment were needle dry biomass ( $\mathrm{mg}$ ), stem dry biomass $(\mathrm{mg})$ and stem length $(\mathrm{mm})$. Proportion of dark red foliage (\%) and root water content (\%) were affected by tailing type treatment. Values are means \pm SE. Different letters indicate significant difference for each growth and health-related parameter between waste rocks and fine tailings.
Growth parameters were negatively correlated with increased concentrations of $\mathrm{Ca}$ and $\mathrm{N}$ encountered in seedling roots and with concentrations of root $\mathrm{Fe}$, and $\mathrm{K}$, and with $\mathrm{N}$ in needles. Negative correlations were also observed between root dry biomass and needle Fe concentration; between stem dry biomass and needle $\mathrm{Ca}$ and $\mathrm{Mg}$ concentrations; between needle dry biomass and the needle concentrations of $\mathrm{Ca}, \mathrm{Mg}$ and Fe. For health-related parameters, the percentage of dark red foliage was positively correlated with increasing concentrations of nutrients in roots $(\mathrm{Ca}, \mathrm{N}$, and $\mathrm{Fe})$ and needles $(\mathrm{K}, \mathrm{Fe})$; it was negatively correlated with root $\mathrm{K}$ concentration. Conversely, the percentage of healthy green foliage was positively correlated with an increased root $\mathrm{K}$ concentration and negatively correlated with the concentration of $\mathrm{Ca}, \mathrm{N}$, and $\mathrm{Fe}$ in roots and with needle $\mathrm{K}$ and Ca concentrations.

The strongest relations of correlation were observed for both growth and health-related parameters with $\mathrm{N}$ and $\mathrm{Ca}$ concentrations. The negative correlations between $\mathrm{N}$ concentration in roots with root, stem and needle dry biomass were of moderate strength $(-0.53 \leq r \leq-0.44)$. The negative coefficients of correlation between dry biomass and $\mathrm{Ca}$ concentrations in roots and in needles were especially strong $(r=-0.63, p$-value $\leq 0.0001$ and $=-0.59, p$-value $\leq 0.0001$, respectively). Finally, root $\mathrm{Ca}$ concentration did also affect at a slightly more moderate level the percentage of dark red foliage $(r=0.47, p$-value $\leq 0.0001)$ and of healthy green foliage $(r=-0.42, p$-value $\leq 0.0001)$.

\section{A Better Nutrition Status for Plants Grown on Coarse Waste Rocks}

Apart from $\mathrm{P}$ for which concentration did not vary significantly during the experiment and remained only slightly below or within normal concentration range observed in healthy coniferous seedlings (Supplementary Figure S2, optimum concentration range indicated by the two dashed lines), tailing type influenced all tested element concentrations in roots and/or needles (Figures 2-4). For all elements, maxima were systematically measured in roots of plants grown on fine tailings but not on coarse waste rocks.

In general, $\mathrm{N}$ concentration was only slightly below optimum and benefited significantly from fine tailing treatment in both roots and needles (Figures $\mathbf{2 A , B}$, p-values $<0.0001$ ) where it exceeded a normal concentration range. A similar pattern was observed for $\mathrm{K}$. In roots, values were within normal ranges (Figure 2C; $p$-value $=0.0112$ ) and reached a maximum in needles of seedlings growing on fine tailings (Figure 2D; $p$-value $<0.0001)$. Soil $\mathrm{Mg}$ concentration was high and seedling root uptake was higher than optimum on both types of soil but particularly on coarse waste rocks (Figure 3A; $p$-value $<0.0001$ ). But because translocation factor (Supplementary Figure S3) was also much lower on waste rocks, it resulted in an opposite pattern in needles: $\mathrm{Mg}$ concentration was normal and even lower than in fine talings-grown plants (Figure 3B; $p$-value $<0.0001$ ). The concentrations of $\mathrm{Ca}$ and $\mathrm{Fe}$ were especially high (Figure 4). Compared to those growing on fine tailings, seedlings growing on waste rocks exhibited lower concentrations of $\mathrm{Ca}$ in roots 


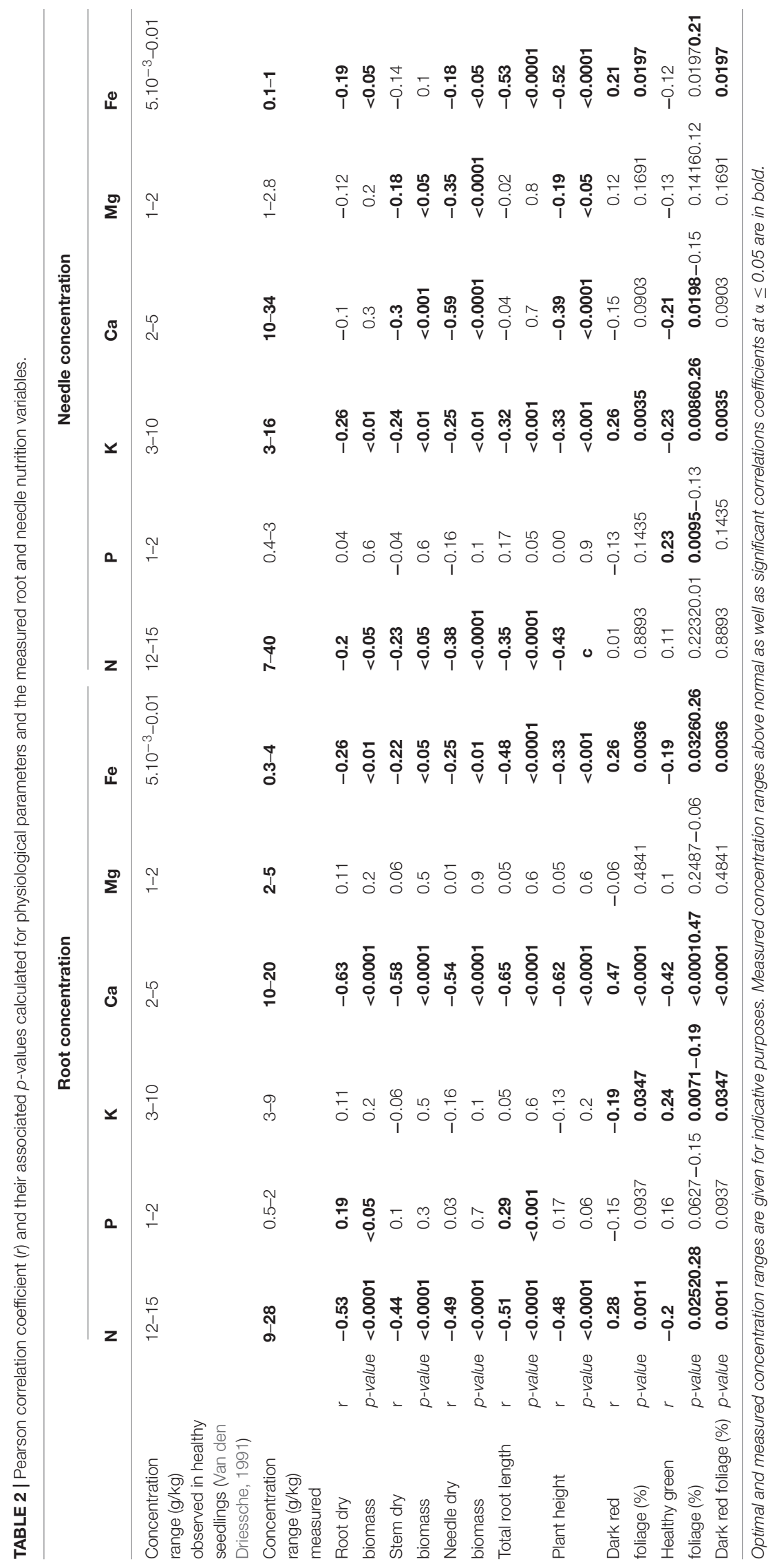


A

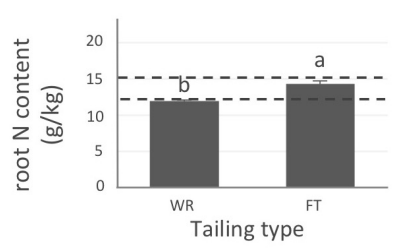

C

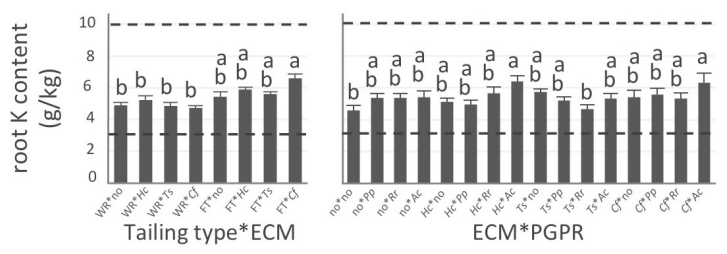

B

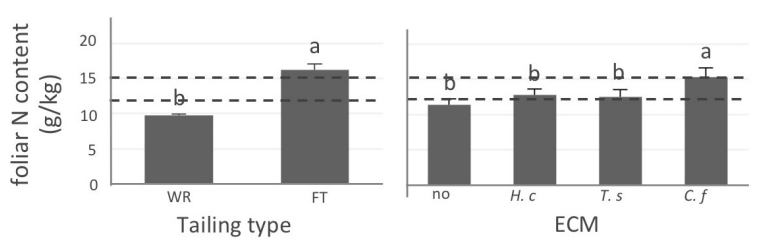

D

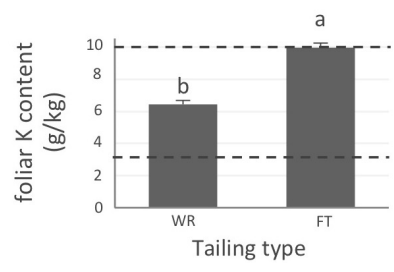

FIGURE 2 | Nitrogen and potassium concentrations of white spruce roots and needles. White spruce seedlings were grown for 32 weeks on waste rocks (WT) or fine tailings (FT) with or without mycorrhizal fungi inoculation (noF $=$ no fungus, $+H c=$ Hebeloma crustuliniforme,$+T s=$ Tricholoma scalpturatum, and $+C f=$ Cadophora finlandia) and with or without inoculation of rhizobacteria $(n \circ B=$ no bacteria, $+P p=P$ seudomonas putida, $+R r=R h i z o b i u m$ radiobacter, and $+A c=$ Azotobacter chroococcum). (A) Root nitrogen $(\mathrm{N})$ content $(\mathrm{g} / \mathrm{kg}$ ) was affected by tailing type treatment $(\mathrm{p}$-value $<0.0001)$; (B) Foliar $\mathrm{N}$ content was independently affected by tailing type and fungal association ( $p$-values $<0.0001)$. (C) For root potassium $(K)$ concentration $(\mathrm{g} / \mathrm{kg})$, there was an interaction between the two factors "Tailing type $x$ fungi" ( $p$-value $=0.0112)$ and between the two factors "fungi $\times$ Bacteria" ( $p$-value $=0.0358)$; $(\mathbf{D})$ foliar $K$ concentration was affected by tailing type ( $p$-value $<0.0001)$. Dotted lines indicate optimal concentration ranges (Van den Driessche, 1991). Values are means $\pm S E$. Different letters indicate significant difference.

A

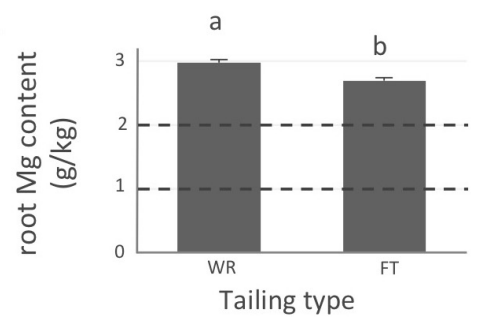

B

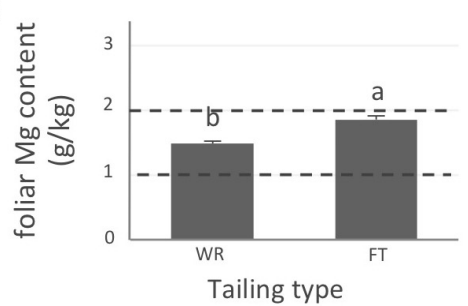

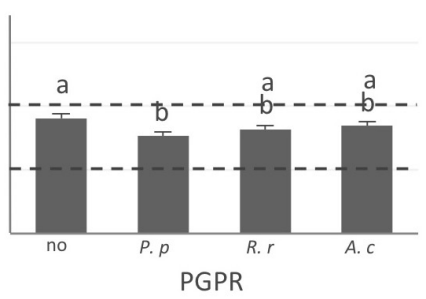

FIGURE 3 | Magnesium concentration of white spruce roots and needles. White spruce seedlings were grown for 32 weeks on waste rocks (WT) or fine tailings (FT) with or without mycorrhizal fungi inoculation (noF = no fungus, $+\mathrm{Hc}=$ Hebeloma crustuliniforme, + Ts $=$ Tricholoma scalpturatum, and $+\mathrm{Cf}=\mathrm{Cadophora} \mathrm{finlandia)} \mathrm{and}$ with or without inoculation of rhizobacteria $(\mathrm{noB}=\mathrm{no}$ bacteria, $+P p=P$ seudomonas putida, $+R r=$ Rhizobium radiobacter, and + Ac $=$ Azotobacter chroococcum). (A) Root magnesium (Mg) content ( $\mathrm{g} / \mathrm{kg}$ ) was affected by tailing type treatment ( $\mathrm{p}$-value $<0.0001)$; (B) foliar Mg content was independently affected by tailing type and by bacterial association ( $p$-values; <0.0001 and =0.0058). Dotted lines indicate optimal concentration ranges (Van den Driessche, 1991$)$. Values are means \pm SE. Different letters indicate significant difference.

and needles (Figures 4A,B; $p$-values $<0.0001$ ). The aboveground concentration of $\mathrm{Ca}$ differed by $23 \%$ in seedlings planted on waste rocks compared to seedlings on fine tailings. A similar pattern was observed for Fe in roots (in interaction with bacterial factor, Figure 4C; $p$-values $=0.0206$ ) and in needles (Figure 4D; $p$-value $<0.0001$ ) where concentration was $38 \%$ lower in plants grown on waste rocks and dropped clearly compared to root concentration (compare $y$-axis scale ranges, Figures 4C,D).

In summary, the nutritional status of plants grown on coarse waste rocks was in general significantly better than those grown in fine tailings. It was closer or within concentration range of healthy white spruce seedlings for $\mathrm{N}$ and $\mathrm{K}$, the availability of which was limited in Sigma-Lamaque gold mine tailings; $\mathrm{Mg}$ concentration fell within normal concentration range in needles; while $\mathrm{Ca}$ and $\mathrm{Fe}$ concentrations were indeed above optima but at significantly lower levels compared to plants grown on fine tailings.

\section{Influence of Symbiotic Association on Plant Nutrition}

As shown in the companion paper (Nadeau et al., 2018), root mycorrhization rate was also greater on waste rocks than on fine tailings, and much higher when plants were inoculated with the fungus $C$. finlandia originally isolated from the mining site. Albeit the concentrations of only a few elements were influenced by mycorrhizal inoculation, C. finlandia is a good ectomycorrhizal fungal candidate: only plants inoculated with C. Finlandia differ from controls regarding foliar $\mathrm{N}$ concentration (Figure 2B), root $\mathrm{K}$ concentration (Figure 2C) and foliar $\mathrm{Fe}$ content (Figure 4D). 
The percentage of root tips colonized by $H$. crustuliniforme had a negative effect on root $\mathrm{N}$ concentration (Table 3) and was positively correlated with root $\mathrm{P}$ concentration (as it was for plants colonized with $T$. scalpturatum). On fine tailings only, the association with $C$. finlandia resulted in a positive translocation factor from the roots to the needles (Supplementary Figure S3). C. finlandia was also the one symbiont for which the negative correlation between root mycorrhization rate and root concentration of $\mathrm{Ca}$ was the strongest $(r=0.66, p$-value $\leq 0.0001)$. It was the only one for which root mycorrhization rate was negatively correlated with root $\mathrm{Fe}$ concentration: the more roots were colonized the least $\mathrm{Ca}$ and $\mathrm{Fe}$ they uptake from a soil where both are found in excess. However, in roots, none of the above-mentioned nutrients was influenced by fungal treatment. Both fungi and rhizobacteria affected the aboveground Fe concentration. There was an interaction between the two treatments (Figure 4D; $p$-value $=0.0472$ ). Compared to seedlings without symbionts, inoculation with either $C$. finlandia alone or with both the fungus T. scalpturatum and the rhizobacterial strain A. chroococcum reduced by half the accumulation of Fe in needles while no other associations improved foliar plant Fe status.

Indeed, association with $A$. chroococcum alone resulted in the highest foliar Fe concentration. $R$. radiobacter treatment also had a negative impact on foliar $\mathrm{Fe}$ concentration (systematically $>0.4 \mathrm{~g} / \mathrm{kg}$ except in combination with $T$. scalpturatum). Besides foliar Fe measurements, it also had a significant impact on root $\mathrm{K}$, foliar $\mathrm{Mg}$, foliar $\mathrm{Ca}$, and root

\section{A}

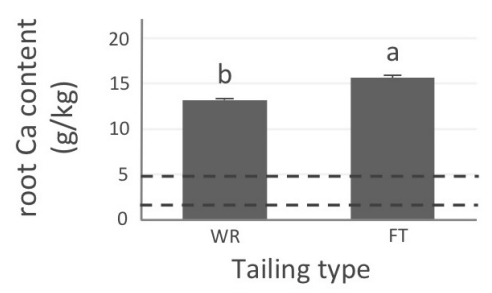

C

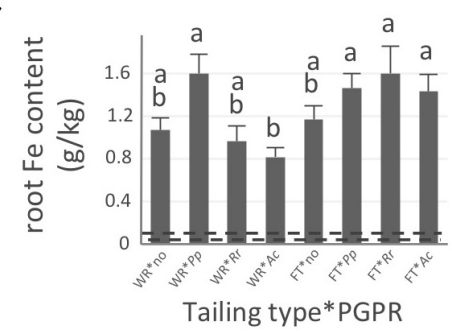

B
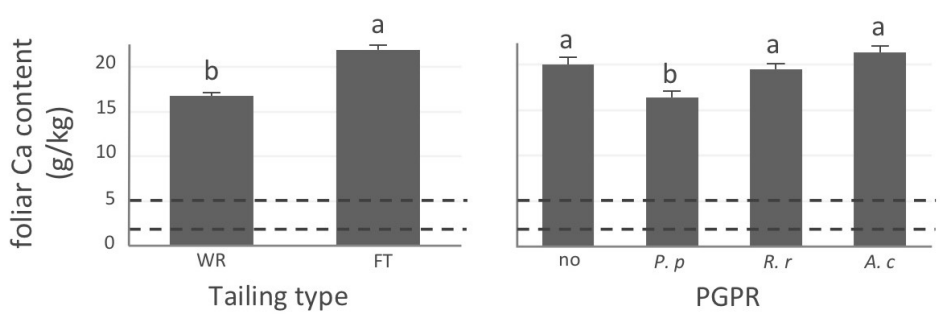

D

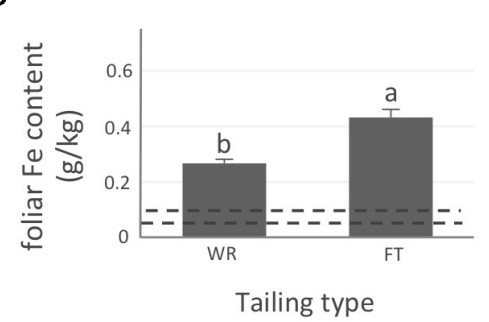

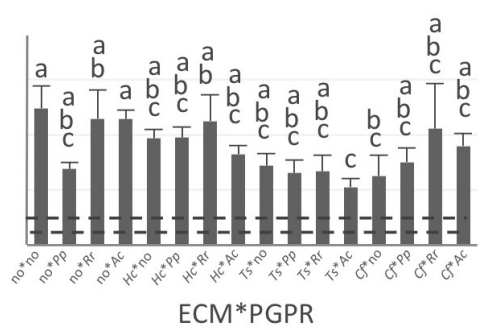

FIGURE 4 | Calcium and iron concentrations of white spruce roots and needles. White spruce seedlings were grown for 32 weeks on waste rocks (WT) or fine tailings (FT) with or without mycorrhizal fungi inoculation (noF $=$ no fungus, $+\mathrm{HC}=$ Hebeloma crustuliniforme, + Ts $=$ Tricholoma scalpturatum, and $+C f=$ Cadophora finlandia) and with or without inoculation of rhizobacteria $(\mathrm{noB}=$ no bacteria, $+P p=$ Pseudomonas putida, $+R r=R$ Rizobium radiobacter, and $+A c=A z o t o b a c t e r$ chroococcum). (A) Root calcium (Ca) content ( $\mathrm{g} / \mathrm{kg}$ ) was affected by tailing type treatment ( $\mathrm{p}$-value < 0.0001); (B) Foliar Ca concentration was independently affected by tailing type and by bacterial association ( $p$-values < 0.0001); (C) for root iron (Fe) concentration $(\mathrm{g} / \mathrm{kg})$, there was an interaction between the two factors "Tailing type $\mathrm{x}$ bacteria" ( $p$-value = 0.0206); (D) Foliar Fe concentration was affected by tailing type treatment $(p$-value $<0.0001)$, there was an interaction between the two factors "fungi $\times$ bacteria" ( $p$-value $=0.0472$ ). Dotted lines indicate optimal concentration ranges (Van den Driessche, 1991). Values are means $\pm \mathrm{SE}$. Different letters indicate significant difference.

TABLE 3 | Pearson correlation coefficient $(r)$ and their associated $p$-values calculated for the proportion of root tips colonized by different fungi and measured root and needle nutrition variables.

\begin{tabular}{|c|c|c|c|c|c|c|c|c|c|c|c|c|c|}
\hline & & \multicolumn{6}{|c|}{ Root content } & \multicolumn{6}{|c|}{ Needle content } \\
\hline Cadophora & $r$ & -0.3 & 0.28 & -0.21 & -0.66 & 0.14 & -0.44 & -0.32 & 0.05 & -0.43 & -0.11 & -0.12 & -0.09 \\
\hline finlandia & $p$-value & 0.0942 & 0.1156 & 0.2426 & $<0.0001$ & 0.4354 & 0.0109 & 0.0764 & 0.7959 & 0.0137 & 0.5308 & 0.5217 & 0.6092 \\
\hline Tricholoma & $r$ & -0.21 & 0.42 & 0.05 & -0.49 & 0.23 & -0.23 & 0.04 & -0.02 & -0.15 & 0.25 & -0.11 & -0.3 \\
\hline scalpturatum & $p$-value & 0.2448 & 0.0175 & 0.7757 & 0.0047 & 0.2048 & 0.207 & 0.8268 & 0.8905 & 0.4071 & 0.1705 & 0.5419 & 0.0966 \\
\hline
\end{tabular}

Significant correlations coefficients at $\alpha \leq 0.05$ are in bold. 
Fe concentrations. On waste rocks, A. chroococcum clearly benefitted white spruces reducing by half root $\mathrm{Fe}$ concentration (Figure 4C, $p$-value $=0.0206$ ) but the same strain had no effect on fine tailings. In the interaction with fungus, the bacterial strain also influenced $\mathrm{K}$ concentration in roots. Values remained within the normal range in all cases, but plants inoculated with A. chroococcum exhibited higher $\mathrm{K}$ concentrations (Figure 2C; $p$-value $=0.0358)$, a minimum average $\mathrm{K}$ concentration was observed for plants associated with both T. scalpturatum fungus and $R$. radiobacter bacterium. At the foliar level, $\mathrm{Mg}$ and $\mathrm{Ca}$ concentrations (Figures 3B, 4B, $p$-values $=0.0058$ and $<0.0001$, respectively) were reduced by $P$. putida inoculation, while plants treated with $A$. chroococcum exhibited concentrations similar to those of plants treated with $R$. radiobacter or to non-inoculated white spruce seedlings. To conclude, the impact of rhizobacteria factor on overall plant nutritional status is complex: A. chroococcum improved Fe nutrition in some cases, $P$. putida improved both foliar $\mathrm{Mg}$ and Ca concentrations, and $R$. radiobacter was the only tested strain with no positive effect.

\section{DISCUSSION}

The results showed the substantial effect of microsymbiont inoculation on white spruce seedlings growing on SigmaLamaque gold mine tailings. In agreement with our main hypothesis, the nutritional status of plants associated with native strains of fungi and rhizobacteria was significantly improved.

\section{Effect of Tailing Type and Particle Size on Plant Performance}

In this experiment, seedlings performed much better on waste rocks than on fine tailings with respect to survival rate, health and growth. On coarse waste rocks, plants also tend to a more balanced mineral content.

Tailings do not contain any nitrogen source and only small concentrations of phosphorus and potassium. Thus one may think macro-elements availability is the limiting factor for plant survival on the mining site. However, increasing concentrations of $\mathrm{N}, \mathrm{P}$, or $\mathrm{K}$ in plant tissue were not associated with improvements in seedling health and growth. On the contrary, high root and foliar $\mathrm{N}$ concentrations were negatively correlated with seedling biomass or percentage of healthy green foliage. While macro-element concentrations in plants grown on waste rocks were within or only slightly below normal concentration ranges, $\mathrm{N}$ and $\mathrm{K}$ were measured at significantly higher levels in plants on fine tailings, mineral weathering being normally higher in finer particle substrates (Modak et al., 2001). In some cases, $\mathrm{N}$ concentration actually exceeded by more than twice the maximum observed in healthy coniferous trees (Van den Driessche, 1991).

Likewise, the concentrations of calcium, magnesium and iron - found in abundance in the substrates - were in general lower in roots and/or needles of plants grown on fine tailings than on waste rocks. $\mathrm{Ca}$ and $\mathrm{Fe}$ concentrations were systematically present at levels largely above the normal concentration ranges. Indeed, in this study, correlation analyses highlight the negative impact of excessive mineral uptake ( $\mathrm{Ca}$ and $\mathrm{Fe}$ but also $\mathrm{N})$ on plant growth- and health-related parameters. Because minerals are less mobile in coarser size residues, white spruce seedlings may perform better on waste rocks than on fine tailings of the Sigma-Lamaque gold mine - where high element concentration rather than nutrient deficiency could limit plant establishment and consequently the development of an effective phytorestoration program.

\section{Allochthonous Microsymbionts Fail to Improve Plant NPK Nutrition}

In our study, microsymbionts played an important role in reducing $\mathrm{Ca}$ and $\mathrm{Fe}$ level but the concentrations of most other elements and especially the primary macro-elements $\mathrm{N}-\mathrm{P}-\mathrm{K}$, were not improved by the different inoculants. Microsymbiotic benefits are often specific to the site, the strain or even to the host involved. For instance regarding nitrogen nutrition, the ability of Azotobacter sp. to fix nitrogen is highly dependant on phosphate availability (Brown et al., 1962; Dynarski and Houlton, 2018); not all strains of Rhizobium radiobacter are capable of fixing nitrogen (Humphry et al., 2007); and the fungus C. finlandia was found important for $\mathrm{N}$ nutrition of Norway spruce (Picea abies, Mrnka et al., 2009) but not for scots pine (Pinus sylvestris, Alberton et al., 2010). Regarding phosphorus nutrition, foliar P does not usually differ between mycorrhizal and non-mycorrhizal seedlings, although hyphae are known to be more effective than roots at P uptake (Smith and Hinckley, 1995). Adeleke et al. (2012) also found that the inoculation of seedlings with ECM fungi enhanced potassium mobilization but did not increase foliar K concentration.

In our experiment, none of the bacterial treatments allowed the increase of seedling $\mathrm{N}$ uptake. Only foliar $\mathrm{N}$ concentration was significantly increased by the association with the fungus C. finlandia, albeit other treatments, including the one without symbionts, fall within normal concentration range. Because the tailings were not sterilized to mimic field conditions, we suspect that some native diazotrophic bacteria may have already been present (Dynarski and Houlton, 2018). The high $\mathrm{pH}$ of the substrate makes it a favorable environment (Brown et al., 1962) for the growth and development of several species capable of improving plant $\mathrm{N}$ nutrition (Damir et al., 2011). Interestingly, when an excessive concentration of nitrogen was measured (associated with disturbance of seedling health and growth), it was often in non-inoculated plants or in plants inoculated with allochthonous microsymbionts. In the context of multi-partite interactions like the ones we established or more complex ones that could occur in the rhizosphere of trees planted on the mine tailings, $\mathrm{N}$-fixing free-living bacteria naturally occurring in situ may coexist better with inoculated fungi or rhizobacteria originating from the same ecosystem (Uroz et al., 2007). Fungi and bacteria already present in the mine tailings (Nadeau and Khasa, 2016) could outcompete microsymbionts that are not well-adapted, hence limiting plant $\mathrm{N}$ nutrition and the successful revegetation with allochtonous microsymbionts.

The tested microsymbiotic associations also failed to clearly improve $\mathrm{P}$ and $\mathrm{K}$ concentrations in roots where they were 
measured under (for $\mathrm{P}$ ) or within normal concentration range (for $\mathrm{P}$ and $\mathrm{K}$ ). Detailed analysis of the data helped us to refine our strategy and to consider, in addition to mycorrhizal fungi inoculation, the use of phosphorus amendment otherwise the only macro-element present in limited quantities in the substrate and within the plant tissues. Indeed, an increasing concentration of $\mathrm{P}$ in plant was shown to benefit seedling growth and health, and also correlated with T. scalpturatum and H. crustuliniforme root colonization rate but not with $C$. finlandia, a fungus yet well adapted to the mining site.

\section{Selection of Native Microsymbiotic Partners for the Successful Alleviation of Element Deleterious Effects}

Among nutrients investigated, plant Ca concentration displayed the strongest negative correlation relationships with general seedling growth and health, followed by iron.

Regarding Mg concentration (measured at a high level in the substrate), on average, it was effectively found above normal concentration range in roots but not in needles. In needles, high levels of $\mathrm{Mg}$ impact growth and may lead to premature fall (Marschner, 1995).

Calcium, also found in excess in the mine tailings, is incidentally known to alleviate $\mathrm{Mg}$ toxicity (Brooks, 1987; Chiarucci et al., 1998). Moreover, the concentrations of both $\mathrm{Mg}$ and $\mathrm{Ca}$ in needles were low in presence of the bacterial strain Pseudomonas putida, which is well characterized for its ability to provide plants with iron through the massive production of siderophores (Bar-Ness et al., 1992). However, P. putida is a versatile species with a broad ability to several traits for adaptations (Matilla et al., 2011; Udaondo et al., 2013). The strain MBN0213 used in this study originated from the mining site. Similar to mycorrhizal fungi that produce calcium oxalate crystals to sequester toxic amounts of Ca (Snetselaar and Whitney, 1990; Arocena et al., 1999), strain MBN0213 may have developed specific mechanisms to reduce Ca toxicity.

Rhizobacteria inoculation did not clearly improve $\mathrm{Fe}$ distribution within plant tissues; only specific combinations resulted in low concentrations. In needles, the allochthonous Azotobacter chroococcum reduced $\mathrm{Fe}$ concentration when inoculated in consortium with T. scalpturatum but not when inoculated alone (in which case average Fe concentration equaled those found in non-inoculated seedlings or in seedlings inoculated with the siderophores-producing $P$. putida). In summary, $P$. putida MBN0213 was the most promising rhizobacterium tested. Although it neither reduced excessive Fe concentration nor improved $\mathrm{N}-\mathrm{P}-\mathrm{K}$ nutrition, it was the only bacterium that minimized $\mathrm{Mg}$ and $\mathrm{Ca}$ concentrations in planta, with the level of Ca being the most limiting factor we identified in this study.

Native fungi of the mining site are also of great interest, especially $C$. finlandia. It is the fungus that colonized seedling roots most efficiently and enhanced seedling health (Nadeau et al., 2018). Also, it was the only microsymbiont whose root colonization rate was negatively correlated with $\mathrm{Fe}$ root concentration and the most strongly correlated with $\mathrm{Ca}$ root uptake. Therefore, C. finlandia is capable of alleviating the deleterious effects of excessive Fe and Ca. On moderately polluted soil, the study of De Maria et al. (2011) demonstrated that an efficient microbial consortium formed by the dual inoculation of C. finlandia and PGPR enhanced goat willow (Salix caprea) phytoextraction efficiency. In the context of the Sigma-Lamaque gold mine tailing revegetation program, we should be able to exploit the synergistic interactions between fungi and bacteria the present study reveals.

\section{AUTHOR CONTRIBUTIONS}

$\mathrm{MN}$ and $\mathrm{DK}$ conceived and designed the experiments. $\mathrm{MN}$ performed the experiments. $\mathrm{MN}$, JL, and $\mathrm{DK}$ analyzed the data and contributed in drafting the manuscript.

\section{FUNDING}

This research project was funded by the Natural Sciences and Engineering Research Council of Canada (NSERC).

\section{ACKNOWLEDGMENTS}

The authors would also like to express their sincere gratitude to Gaétan Daigle and Marc Mazerolle for their statistical guidance, Alain Brousseau for conducting seedling nutrient analyses, and Mathieu Boudreau for his assistance. Furthermore, the authors are grateful to Steeve Pépin and Marie Coyea for their advice and assistance related to the equipment used for measuring seedling health and growth. They also thank François Larochelle, Marie-Andrée Paré, André Gagné, JeanGuy Catford, Aida Azaiez, Marie-Ève Beaulieu, and Laurent Fontaine who contributed in some way to the completion of this study. Last but not least, the authors are thankful to Dr. Line Lapointe (Université Laval) and Dr. Suzanne Simard (University of British Columbia) for their useful comments and constructive review of the first draft of this manuscript.

\section{SUPPLEMENTARY MATERIAL}

The Supplementary Material for this article can be found online at: https://www.frontiersin.org/articles/10.3389/fpls.2018.01268/ full\#supplementary-material

FIGURE S1 | Illustrations and design of the experiment. Mycorrhizal fungi and rhizobacteria used in this $\mathbf{( A )}$ glasshouse experiment were either $\mathbf{( B )}$ native from the Sigma-Lamaque gold mine site (Tricholoma scalpturatum (Ts), Cadophora finlandia (Cf); Pseudomonas putida (Pp), Rhizobium radiobacter (Rr)), or isolated from a natural forest stand (Hebeloma crustuliniforme $(\mathrm{Hc})$ ) or of commercial origin for Azotobacter chroococcum (Ac). White spruce saplings were either planted in (C) waste rocks or in fine tailings. (D) Randomized complete block (RCB) design with three crossed fixed factors: tailing type [fine tailing $(F T)$ in regular font, waste 
rocks (WT) in bold]; fungi [none (noF) in black, Ts: green font, Cf: blue font, Hc: red font]; and bacteria [none (noB): no background, Rr: background in red, Pp: background in blue, Ac: background in green] for a total of 32 treatments, 4 blocks, 3 replicates per treatment per block, and 384 experimental units.

FIGURE S2 | Phosphorus $(\mathrm{P})$ concentration of white spruce roots and needles White spruce seedlings were grown for 32 weeks on waste rocks (WT) or fine tailings (FT) with or without mycorrhizal fungi inoculation (noF = no fungus, $+H$ $c=$ Hebeloma crustuliniforme, $+T S=$ Tricholoma scalpturatum, and $+C f=$ Cadophora finlandia) and with or without inoculation of rhizobacteria

\section{REFERENCES}

Adeleke, R. A., Cloete, T. E., Bertrand, A., and Khasa, D. P. (2012). Iron ore potential of ectomycorrhizal plants. Mycorrhiza 22, 535-544. doi: 10.1007/ s00572-012-0431-5

Alberton, O., Kuyper, T. W., and Summerbell, R. C. (2010). Dark septate root endophytic fungi increase growth of Scots pine seedlings under elevated $\mathrm{CO}_{2}$ through enhanced nitrogen use efficiency. Plant Soil 328, 459-470. doi: 10.1007/ s11104-009-0125-8

Allen, E. B., Allen, M. F., Egerton-Warburton, L., Corkidi, L., and GomezPompa, A. (2003a). Impacts of early- and late-seral mycorrhizae during restoration in seasonal tropical forest, Mexico. Ecol. Appl.. 13, 1701-1717.

Allen, M. F., Swenson, W., Querejeta, J. I., Egerton-Warburton, L. M., and Treseder, K. K. (2003b). Ecology of mycorrhizae: a conceptual framework for complex interactions among plants and fungi. Annu. Rev. Phytopathol. 41, 271-303.

Amin, A., and Latif, Z. (2016). Screening of mercury-resistant and indole-3-acetic acid producing bacterial-consortium for growth promotion of Cicer arietinum L. J. Basic Microbiol. 57, 204-217. doi: 10.1002/jobm.201600352

Arocena, J. M., Glowa, K. R., Massicotte, H. B., and Lavkulich, L. (1999). Chemical and mineral composition of ectomycorrhizosphere soils of subalpine fir (Abies lasiocarpa (Hook.) Nutt.) in the Ae horizon of a luvisol. Can. J. Soil Sci. 79, 25-35. doi: 10.4141/S98-037

Balogh-Brunstad, Z., Keller, C. K., Dickinson, J. T., Stevens, F., Li, C. Y., and Bormann, B. T. (2008). Biotite weathering and nutrient uptake by ectomycorrhizal fungus, Suillus tomentosus, in liquid-culture experiments. Geochim. Cosmochim. Acta 72, 2601-2618. doi: 10.1016/j.gca.2008.04.003

Bar-Ness, E., Hadar, E. Y., Chen, Y., Shanzer, A., and Libman, J. (1992). Iron uptake by plants from microbial siderophores: a study with 7-nitrobenz-2 oxa-1,3diazole desferrioxamine as fluorescent ferrioxamine B analog. Plant Physiol. 99, 1329-1335. doi: 10.1104/pp.99.4.1329

Beauregard, A. J., Gaudreault, D., and D’Amours, C. (2012). Technical Report on the Lamaque Property for Integra Gold Corp, NI 43-101. Québec, QC: Technical Report Lamaque Project Québec.

Brooks R. R. (1987). Serpentine and Its Vegetation: A Multidisciplinary Approach. Portland, OR: Dioscorides Press.

Brown, M. E., Burlingham, S. K., and Jackson, R. M. (1962). Studies on Azotobacter species in soil: II. Populations of Azotobacter in the rhizosphere and effects of artificial inoculation. Plant Soil. 17, 320-332. doi: 10.1007/BF01377671

Callender, K. L., Roy, S., Khasa, D. P., Whyte, L. G., and Greer, C. W. (2016). Actinorhizal alder phytostabilization alters microbial community dynamics in gold mine waste rock from Northern Quebec: a greenhouse study. PLoS One 11:e0150181. doi: 10.1371/journal.pone.0150181

Calvaruso, C., Turpault, M., and Frey-Klett, P. (2006). Root-associated bacteria contribute to mineral weathering and to mineral nutrition in trees: a budgeting analysis. Appl. Environ. Microbiol. 72, 1258-1266. doi: 10.1128/AEM.72.2. 1258-1266.2006

Chiarucci, A., Maccherini, S., Bonini, I., and De Dominicis, V. (1998). Effects of nutrient addition on species diversity and ground cover of 'serpentine' vegetation. Plant Biosyst. 132, 143-150. doi: 10.1080/11263504.1998.10654199

Dahlberg, A. (2001). Community ecology of ectomycorhizal fungi: an advancing interdisciplinary field. New Phytol. 150, 555-562. doi: 10.1046/j.1469-8137. 2001.00142.x

Damir, O., Mladen, P., Bozidar, S., and Srdan, N. (2011). Cultivation of the bacterium Azotobacter chroococcum for the preparation of biofertilizers. Afr. J. Biotechnol. 10, 3104-3111. doi: 10.5897/AJB10.1086
(noB $=$ no bacteria,$+P p=P$ seudomonas putida,$+R r=$ Rhizobium radiobacter and $+A c=$ Azotobacter chroococcum). Dotted lines indicate optimal concentration ranges (Van den Driessche, 1991). Values are means \pm SE.

FIGURE S3 | Translocation factors. White spruce seedlings were grown for 32 weeks on waste rocks (WT) or fine tailings (FT) with or without mycorrhizal fungi inoculation (noF $=$ no fungus, $+\mathrm{Hc}=$ Hebeloma crustuliniforme,$+T s=$ Tricholoma scalpturatum, and $+C f=$ Cadophora finlandia) and with or without inoculation of rhizobacteria $(\mathrm{noB}=$ no bacteria, $+P p=$ Pseudomonas putida, $+R r=$ Rhizobium radiobacter, and $+A c=$ Azotobacter chroococcum).

De Maria, S., Rivelli, A. R., Kuffner, M., Sessitsch, A., Wenzel, W. W., Gorfer, M., et al. (2011). Interactions between accumulation of trace elements and macronutrients in Salix caprea after inoculation with rhizosphere microorganisms. Chemosphere 84, 1256-1261. doi: 10.1016/j.chemosphere. 2011.05.002

Dixon, R. K., and Buschena, C. A. (1988). Response of ectomycorrhizal Pinus banksiana and Pices glauca to heavy metals in soil. Plant Soil 105, 265-271. doi: $10.1007 / \mathrm{BF} 02376791$

Dynarski, K. A., and Houlton, B. Z. (2018). Nutrient limitation of terrestrial free-living nitrogen fixation. New Phytol. 217, 1050-1106. doi: 10.1111/nph. 14905

Hobbie, E. A., Macko, S. A., and Shugart, H. H. (1998). Patterns in N dynamics and $\mathrm{N}$ isotopes during primary succession in glacier bay, Alaska. Chem. Geol. 152, 3-11. doi: 10.1016/S0009-2541(98)00092-8

Humphry, D. R., Andrews, M., Santos, S. R., James, E. K., Vinogradova, L. V., Perin, L., et al. (2007). Phylogenetic assignment and mechanism of action of a crop growth promoting Rhizobium radiobacter strain used as a biofertiliser on graminaceous crops in Russia. Antonie Van Leeuwenhoek 91, 105-113. doi: $10.1007 / \mathrm{s} 10482-006-9100-\mathrm{z}$

Jumpponen, A., Trappe, J. M., and Cazares, E. (2002). Occurrence of ectomycorrhizal fungi on the forefront of retreating Lyman Glacier (Washington. USA) in relation to time since deglaciation. Mycorrhiza 12, 43-49. doi: 10.1007/s00572-001-0152-7

Kalra, Y. P. (1998). Handbook of Reference Methods for Plant Analysis. Boca Raton, FL: CRC Press.

Khan, A. G. (2006). Mycorhizoremediation - an enhanced form of phytoremediation. J. Zhejiang Univ.-Sci. B. 7, 503-514. doi: 10.1631/jzus. 2006.B0503

Marschner, H. (1995). Mineral Nutrition of Higher Plants. London: Academic Press. Marshall, V. G. (2000). Impacts of forest harvesting on biological processes in northern forest soils. For. Ecol. Manage. 133, 43-60. doi: 10.1016/S03781127(99)00297-2

Matilla, M. A., Pizarro-Tobías, P., Roca, A., Fernández, M., Duque, E., Molina, L., et al. (2011). Complete genome of the plant-growth promoting rhizobacterium Pseudomonas putida BIRD-1. J. Bacteriol. 193:1290.

Modak, J. M., Vasan, S. S., and Natarajan, K. A. (2001). "Calcium removal from bauxite using Paenibacillus polymyxa," in Mineral Biotechnology: Microbial Aspects of Mineral Beneficiation, Metal Extraction, and Environmental Control, eds S. K. Kawatra and K. A. Natarajan (Englewood, CO: Society for Mining, Metallurgy, and Exploration), 13-25.

Mrnka, L., Tokárová, H., Vosátka, M., and Matějka, P. (2009). Interaction of soil filamentous fungi affects needle composition and nutrition of Norway spruce seedlings. Trees 23, 887-897. doi: 10.1007/s00468-0090330-3

Nadeau, M. B. (2014). Development of a New Green Technology for the Vegetation of Abandoned Gold Mine Tailings Using Specific Symbionts Associated with Pices glauca. Master's thesis, Université Laval, Faculté de foresterie, de géographie et de géomatique, Québec, QC.

Nadeau, M. B., and Khasa, D. P. (2016). Edaphic selection pressures as drivers of contrasting white spruce ectomycorrhizal fungal community structure and diversity in the Canadian boreal forest of AbitibiTémiscamingue region. PLoS One 11:e0166420. doi: 10.1371/journal.pone.016 6420

Nadeau, M. B., Laur, J., and Khasa, D. P. (2018). Mycorrhizae and rhizobacteria on Precambrian rocky gold mine tailings: I. Mine-adapted symbionts promote 
white spruce health and growth. Front. Plant Sci. 9:1267. doi: 10.3389/fpls.2018. 01267

Nadeau, M. B., Quoreshi, A., and Khasa, D. P. (2016). "Ecological restoration and bioremediation of canadian mining boreal ecosystems," in Microbes for Restoration of Degraded Ecosystems, eds D. J. Bagyaraj and Jamaluddin (New Delhi: New India Publishing Agency), 259-284.

Nienstaedt, H., and Zasada, J. C. (1990). Pices glauca (Moench) Voss. Silvics of North America, Vol. 1. Conifers, CO: United States Forest Service.

Quoreshi, A. M., and Khasa, D. P. (2008). Effectiveness of mycorrhizal inoculation in the nursery on root colonization, growth, and nutrient uptake of aspen and balsam poplar. Biomass Bioenergy 32, 381-391. doi: 10.1016/j.biombioe.2007. 10.010

Quoreshi, A. M., Roy, S., Greer, C. W., and Beaudin, J. (2007). Inoculation of green alder (Alnus crispa) with Frankia-ectomycorrhizal fungal inoculant under commercial nursery production conditions. Native Plants J. 8, 271-281. doi: 10.2979/NPJ.2007.8.3.271

Rodríguez, H., and Fraga, R. (1999). Phosphate solubilizing bacteria and their role in plant growth promotion. Biotechnol. Adv. 17, 319-339. doi: 10.1016/S0734-9750(99)00014-2

Roy, S., Khasa, D. P., and Greer, C. W. (2007). Combining alders, frankiae, and mycorrhizae for the revegetation and remediation of contaminated ecosystems. Can. J. Bot. 85, 237-251. doi: 10.1139/B07-017

Smith, S. E., and Read, D. J. (2008). Mycorrhizal Symbiosis, 3rd Edn. London: Academic Press.

Smith, W. K., and Hinckley, T. M. (1995). Resource Physiology of Conifers Acquisition, Allocation and Utilization. London: Academic Press.

Snetselaar, K. M., and Whitney, K. D. (1990). Fungal calcium oxalate in mycorrhizae of Monotropa uniflora. Can. J. Bot. 68, 533-543. doi: 10.1139/b 90-074

Sritongon, K., Mongkolthanaruk, W., Boonlue, S., Jogloy, S., Puangbut, D., and Riddech, N. (2017). Rhizobacterial candidates isolated from Jerusalem artichoke (Helianthus tuberosus L.) rhizosphere for host plant growth promotion. Chiang Mai J. Sci. 44, 83-93.

Sutton, R. F. (1973). Histoire Naturelle de l'Eipinette Blanche (Pices glauca (Moench) Voss). Ottawa, ON: Ministeİre de l'Environnement, Service Canadien des Forêts, Publication 1250f.

Taner, M. F., Trudel, P., and Perrault, G. (1986). Géochimie de la biotite associée à certains gisements d'or de Val d'Or, Malartic et Chibougamau, Québec. Can. Mineral. 24, 761-774.

Tilak, K. V. B. R., Ranganayaki, N., Pal, K. K., De, R., Saxena, A. K., Nautiyal, C. S., et al. (2005). Diversity of plant growth and soil health supporting bacteria. Curr. Sci. 89, 136-150.
Trowbridge, J., and Jumpponen, A. (2004). Fungal colonization of shrub willow roots at the forefront of a receding glacier. Mycorrhiza 14, 283-293. doi: 10.1007/s00572-003-0264-3

Udaondo, Z., Molina, L., Daniels, C., Gómez, M. J., Molina-Henares, M. A., Matilla, M., et al. (2013). Metabolic potential of the organic-solvent tolerant Pseudomonas putida DOT-T1E deduced from its annotated genome. Microb. Biotechnol. 6, 598-611. doi: 10.1111/1751-7915. 12061

Uroz, S., Calvaruso, C., Turpault, M. P., and Frey-Klett, P. (2009). Mineral weathering by bacteria: ecology, actors, and mechanisms. Trends Microbiol. 17, 378-387. doi: 10.1016/j.tim.2009.05.004

Uroz, S., Calvaruso, C., Turpault, M. P., Pierrat, J. C., Mustin, C., and FreyKlett, P. (2007). Effect of the mycorrhizosphere on the genotypic and metabolic diversity of the bacterial communities involved in mineral weathering in a forest soil. Appl. Environ. Microbiol. 73, 3019-3027. doi: 10.1128/AEM.00 121-07

Van den Driessche, R. (1991). Mineral Nutrition of Conifer Seedlings. Boca Raton, FL: CRC Press.

Vodouhe, G. F., and Khasa, D. P. (2015). Local communities' perception of mine sites restoration in Abitibi (Quebec). Int. J. Phytoremed. 17, 962-972. doi: 10. 1080/15226514.2014.981238

Zahid, M., Abbasi, M. K., Hameed, S., and Rahim, N. (2015). Isolation and identification of indigenous plant growth promoting rhizobacteria from Himalayan region of Kashmir and their effect on improving growth and nutrient contents of maize (Zea mays L.). Front. Microbiol. 2015:207.

Zahoor, M., Irshad, M., Rahman, H., Qasim, M., Gul Afridi, S., Qadir, M., et al. (2017). Alleviation of heavy metal toxicity and phytostimulation of Brassica campestris L. by endophytic Mucor sp. MHR-7. Ecotoxicol. Environ. Saf. 142, 139-149. doi: 10.1016/j.ecoenv.2017. 04.005

Conflict of Interest Statement: The authors declare that the research was conducted in the absence of any commercial or financial relationships that could be construed as a potential conflict of interest.

Copyright (C) 2018 Nadeau, Laur and Khasa. This is an open-access article distributed under the terms of the Creative Commons Attribution License (CC BY). The use, distribution or reproduction in other forums is permitted, provided the original author(s) and the copyright owner(s) are credited and that the original publication in this journal is cited, in accordance with accepted academic practice. No use, distribution or reproduction is permitted which does not comply with these terms. 